\title{
BMJ Open Discrepancies in self-reported financial conflicts of interest disclosures by physicians: a systematic review
}

\author{
Cameron Taheri (D) , ${ }^{1}$ Abirami Kirubarajan (D) , ${ }^{1,2}$ Xinglin Li, ${ }^{1}$ Andrew C L Lam, ${ }^{1}$ \\ Sam Taheri, ${ }^{3}$ Nancy F Olivieri ${ }^{4}$
}

To cite: Taheri C, Kirubarajan A, Li X, et al. Discrepancies in self-reported financial conflicts of interest disclosures by physicians: a systematic review. BMJ Open 2021;11:e045306. doi:10.1136/ bmjopen-2020-045306

- Prepublication history and supplemental material for this paper is available online. To view these files, please visit the journal online (http://dx.doi. org/10.1136/bmjopen-2020045306).

Received 27 September 2020 Revised 19 February 2021 Accepted 23 February 2021

Check for updates

(C) Author(s) (or their employer(s)) 2021. Re-use permitted under CC BY-NC. No commercial re-use. See rights and permissions. Published by BMJ.

${ }^{1}$ Faculty of Medicine, University of Toronto, Toronto, Ontario,

Canada

${ }^{2}$ Institute of Health Policy Management and Evaluation, University of Toronto, Toronto, Ontario, Canada

${ }^{3}$ Faculty of Dentistry, University of Toronto, Toronto, Ontario, Canada

${ }^{4}$ Toronto General Hospital Research Institute, Toronto General Hospital, Toronto, Ontario, Canada

\section{Correspondence to} Cameron Taheri; cameron.taheri@mail.utoronto. ca

\section{ABSTRACT}

Background There is a high prevalence of financial conflicts of interest (COI) between physicians and industry. Objectives To conduct a systematic review with metaanalysis examining the completeness of self-reported financial $\mathrm{COI}$ disclosures by physicians, and identify factors associated with non-disclosure.

Data sources MEDLINE, Embase and PsycINFO were searched for eligible studies up to April 2020 and supplemented with material identified in the references and citing articles.

Data extraction and synthesis Data were independently abstracted by two authors. Data synthesis was performed via systematic review of eligible studies and randomeffects meta-analysis.

Main outcomes and measures The proportion of discrepancies between physician self-reported disclosures and objective payment data was the main outcome. The proportion of discrepant funds and factors associated with non-disclosure were also examined.

Results 40 studies were included. The pooled proportion of COI discrepancies at the article level was $81 \%$ (range: 54\%-98\%; $95 \% \mathrm{Cl} 72 \%$ to $89 \%$ ), $79 \%$ at the payment level (range: $71 \%-89 \%$; $95 \% \mathrm{Cl} 67 \%$ to $89 \%$ ), $93 \%$ at the authorship level (range: $71 \%-100 \% ; 95 \% \mathrm{Cl} 79 \%$ to $100 \%$ ) and $66 \%$ at the author level (range: $8 \%-99 \%$; $95 \% \mathrm{Cl} 48 \%$ to $78 \%$ ). The proportion of funds discrepant was $33 \%$ (range: $2 \%-77 \%$; $95 \% \mathrm{Cl} 12 \%$ to $58 \%$ ). There was high heterogeneity between studies across all five analyses $\left(I^{2}=94 \%-99 \%\right)$. Most undisclosed COI were related to food and beverage, or travel and lodging. While the most common explanation for failure to disclose was perceived irrelevance, a median of $45 \%$ of non-disclosed payments were directly or indirectly related to the work. A smaller monetary amount was the most common factor associated with nondisclosure.

Conclusions Physician self-reports of financial COI are highly discrepant with objective data sources reporting payments from industry. Stronger policies are required to reduce reliance on physician self-reporting of financial $\mathrm{COI}$ and address non-compliance.

\section{BACKGROUND}

Financial conflicts of interest (COI) between physicians and industry commonly occur, and are a long-standing area of the public concern. ${ }^{12}$ They occur in situations where

\section{Strengths and limitations of this study}

- The study systematically reviewed the literature to characterise discrepancies in self-reported payments across multiple settings and disciplines.

- The results were stratified across different levels in order to provide more accurate estimates of discrepant reporting.

- The population and methodologies used for assessment of conflicts of interest are not the same across studies resulting in high heterogeneity.

- Many of the objective data sources used in the included studies relied on disclosures by industry, which may have inconsistencies.

- The study is largely limited to physicians in the USA and may not be generalisable to other countries.

a person has a moral obligation to exercise judgement in another's service and, at the same time, an interest tending to interfere with the proper exercise of judgement in that relationship. Under this definition, 'judgement' refers to intelligent activity requiring more than mechanical rule following; 'interest' refers to personal financial benefit, family interest or any special influence or loyalty which could undermine the performance of one's duty to exercise one's judgement objectively. ${ }^{3}$ Financial COI have the potential to undermine the integrity of medical research, education and practice. $^{3-5}$ Considerable evidence indicates that financial COI may influence the conduct and reporting of research, increasing the likelihood of research outcomes favouring the sponsor (usually the pharmaceutical or device industry). ${ }^{16}$ Additionally, financial COI may be associated with inappropriate prescribing patterns. ${ }^{7}$

Financial COI occur in situations in which there is transfer of payment from industry to physicians. This is independent of whether these payments are disclosed. The National Academy of Medicine, a US non-profit 
organisation, which is independent of government and provides policy recommendations for public health and science, asserts that accurate disclosures of COI protect the integrity of professional judgement and preserve the public trust in physicians. ${ }^{5}$ Over the past decade, many academic institutions and medical journals have adopted guidelines which guide disclosures of financial COI in a putative effort to increase transparency, encourage critical appraisal of research findings, and enable research into the effects of COI. ${ }^{8}$

While there has emerged credible criticism that disclosure is not a solution to the management of COI, ${ }^{910}$ financial COI disclosures have become a quintessential part of conducting and publishing research, delivering academic presentations and educating medical students. Complicating the issue is that disclosure of financial COIs relies almost entirely on self-reporting by those benefiting from financial gain. There has traditionally been no means of verification of the correlation between payments received and disclosure. Indeed, many physicians have been reported to omit, or incompletely disclose relevant COI, even in situations where guidelines require this disclosure, ${ }^{211-14}$ resulting in incorrect information provided to those reading, interpreting or using the data reported. The extent of and factors associated with this underreporting of financial COI by physicians may be less well studied than warranted by this important issue. To date, there has not been a systematic search of the literature identifying studies comparing actual and disclosed financial COI. Our study aims to systematically examine the literature on completeness of self-reported financial COI disclosures by physicians, and identify the factors associated with non-disclosure.

\section{METHODS}

This systematic review was conducted according to the standards and guidelines established by the Preferred Reporting Items for Systematic Reviews and MetaAnalyses (PRISMA) and the fourth edition of the Joanna Briggs Institute Reviewer's Manual. ${ }^{15}{ }^{16}$ Methods of the analysis and inclusion criteria were specified in advance and documented. Our protocol is publicly available. ${ }^{17}$

\section{Eligibility Criteria}

We included studies that sought to examine discrepancies between financial COI which were reported by physicians, and the objective data which documented payments from industry to the physicians as either the primary or secondary objective. We considered a discrepancy to be present if data provided information about relevant financial support that was not reported by the physicians themselves. We considered objective payment data to be any data that was not reported by physicians themselves. Comparisons between self-reported disclosures were not eligible for our study as these were not considered to be complete. We examined only original, peer-reviewed literature in the English language including cross-sectional analyses, prospective cohorts and retrospective cohorts. Published conference posters and abstracts were not eligible for inclusion as we required full-text manuscripts to optimise the completeness of our data. Articles were excluded if they did not focus on physicians, did not assess COI involving payments from the pharmaceutical (or device manufacturing) industry, or if they did not have available an objective comparator. We reviewed studies that focused on disclosures in any setting, such as research publications, clinical practice guidelines, academic presentations or conference committees.

\section{Information sources}

We consulted a University of Toronto research librarian to help develop the search strategy. We searched Ovid MEDLINE (1946-April 2020), Ovid Embase (1947-April 2020) and PsycINFO (1806-April 2020) using a combination of both MeSH subject headings (exploded) and key words. Subject-specific search terms adapted from previously published systematic reviews on financial COI ('COI', 'financial support' and 'funding') were combined with a filter to retrieve studies related to physicians. ${ }^{6} 1819$ The search strategy is included in online supplemental appendix 1. In addition, we reviewed the references of included papers and searched for studies that have cited these papers using SCOPUS.

\section{Study selection}

Study selection was completed in duplicate by two independent, parallel reviewers (AK and XL) using title, abstract and full-text screening. Disagreements between reviewers were resolved independently by a blinded third reviewer (CT). Covidence was used for both data management and screening. ${ }^{20}$

\section{Data collection}

To refine extraction categories we developed a data extraction sheet a priori and pilot tested it on 10 randomly selected studies we had included. Data were extracted in duplicate by two independent, parallel reviewers (CT and $\mathrm{XL}$ ). Disagreements were resolved by discussion between the two reviewers and subsequent consultation with a third author (AK).

From each study, we extracted the clinical focus, study design, primary objective, sources of data collection, time of payments, how COI were defined, number and monetary amount of total COI, number and monetary amount of undisclosed COI, number of relevant undisclosed COI, types of undisclosed COI, factors associated with undisclosed COI, reasons for non-disclosure and association of nondisclosure with study outcomes.

We assessed the risk of bias of each included study using a modified version of the Joanna Briggs Institute (JBI) Critical Appraisal Checklist for Studies Reporting Prevalence data. The JBI checklist is used to determine the extent to which a study has addressed the possibility of bias in its design, conduct and analysis. Individual studies are scored as either 'yes', 'no', or 'unclear' for each 
checklist item. We considered a sample greater than 1000 to be adequate in the absence of an appropriate sample size calculation. The risk-of-bias assessment was done in duplicate by two independent, parallel reviewers (AK and XL). Disagreements were resolved by discussion between the two reviewers and subsequent consultation with a third author (CT).

\section{Data synthesis}

The included studies were described and summarised by narrative synthesis. We also conducted an exploratory meta-analysis of the studies which reported the data necessary to compute the proportion of payments discrepant and the amount of funds discrepant.

\section{Statistical analyses and outcomes}

Our primary outcome was the proportion of COI which was discrepant, that is, the proportion in which objective documentation of funding had not been self-reported. Our secondary outcome was the proportion of funds discrepant, that is the amount of funds (US dollars) which had not been self-reported. Disclosures that were reported by physicians, but not reported by the objective data source, were not considered to be discrepancies in this study.

Data were stratified into four groups according to whether they described discrepancies among authorships, authors, articles or payments. Refer to table 1 below to better understand how we use these terms. In each case, the proportion of COI identified as discrepant between self-reporting and objective was defined as the number undisclosed COI over the total number of COI.

Each payment was treated as equal regardless of the amount of funding or the amount discrepant. The proportion of funds identified as discrepant between self-reporting and objective data was defined as the undisclosed funds as a proportion of the funds recorded in the payment database. The proportion of discrepant COI and the proportion of discrepant funds were pooled in an exploratory meta-analysis and analysed using a random-effects model. Exploratory analyses were performed to determine the degree of heterogeneity between studies and to quantitatively determine the proportion of COI and funds discrepant across studies. A random-effects model was used because of the expected methodological and sample heterogeneity between studies. The $\mathrm{I}^{2}$ statistic was used to measure heterogeneity between studies and $p<0.05$ was considered statistically significant. Statistical analysis was performed using MedCalc Statistical Software V.19.2.6. ${ }^{21}$

\section{RESULTS}

\section{Search results}

Figure 1 illustrates the PRISMA flow diagram. Searches and other data sources provided a total of 8460 citations. After removing duplicates, 5845 studies remained. Of these, we discarded 5782 studies after reviewing the abstracts which indicated the papers did not meet the inclusion criteria. One additional study was discarded because the full text of the study was not available. We assessed the full text of the remaining 63 citations. We identified a total of 40 studies for inclusion in the systematic review, 12 of which were identified by searching reference lists and citing articles. Inter-rater reliability for study screening for titles/abstract and full-text screening was $99.5 \%$ and $91.2 \%$, respectively. The authors were in substantial agreement or better with a calculated kappa of 0.77 and 0.81 , respectively.

\section{Characteristics of included studies}

Table 2 summarises the characteristics of the 40 studies included in this analysis. All studies had a cross-sectional design. Thirty-eight studies were conducted in the USA and two in Denmark. ${ }^{22}{ }^{23}$ Six studies assessed disclosures from academic meetings, ${ }^{11} 1324-27$ 10 assessed disclosures in clinical practice guidelines, ${ }^{23}{ }^{28-36} 22$ assessed those in other publications ${ }^{12} 142237-56$ and 1 assessed those in both an academic meeting and publications..$^{53}$ All studies

\begin{tabular}{lll}
\hline Table 1 & Definitions of groups used to stratify data & \\
\hline Group & Definition & Example \\
\hline Authorship & $\begin{array}{l}\text { One instance of disclosure by one individual. One } \\
\text { authorship may involve multiple transactions. }\end{array}$ & $\begin{array}{l}\text { Sorting by authorship can involve identifying any } \\
\text { discrepancies in COI reporting by one author in a } \\
\text { single published work. }\end{array}$ \\
Author & $\begin{array}{l}\text { A unique individual who can have more than one } \\
\text { authorship. An author may be involved in multiple } \\
\text { authorships. }\end{array}$ & $\begin{array}{l}\text { Sorting by author can involve identifying any } \\
\text { discrepancies in COI reporting by one author among a } \\
\text { number of publications. }\end{array}$ \\
Article & $\begin{array}{l}\text { A group of individuals with authorships for a single } \\
\text { published work }\end{array}$ & $\begin{array}{l}\text { Sorting by article involves identifying any } \\
\text { discrepancies in COI reporting by any author of a } \\
\text { single published work. }\end{array}$ \\
Payment & A single transaction between industry and authors. & $\begin{array}{l}\text { Sorting by payment involves identifying any } \\
\text { discrepancies in COI reporting by one individual for a } \\
\text { single transaction. }\end{array}$ \\
\hline
\end{tabular}

COI, conflicts of interest. 


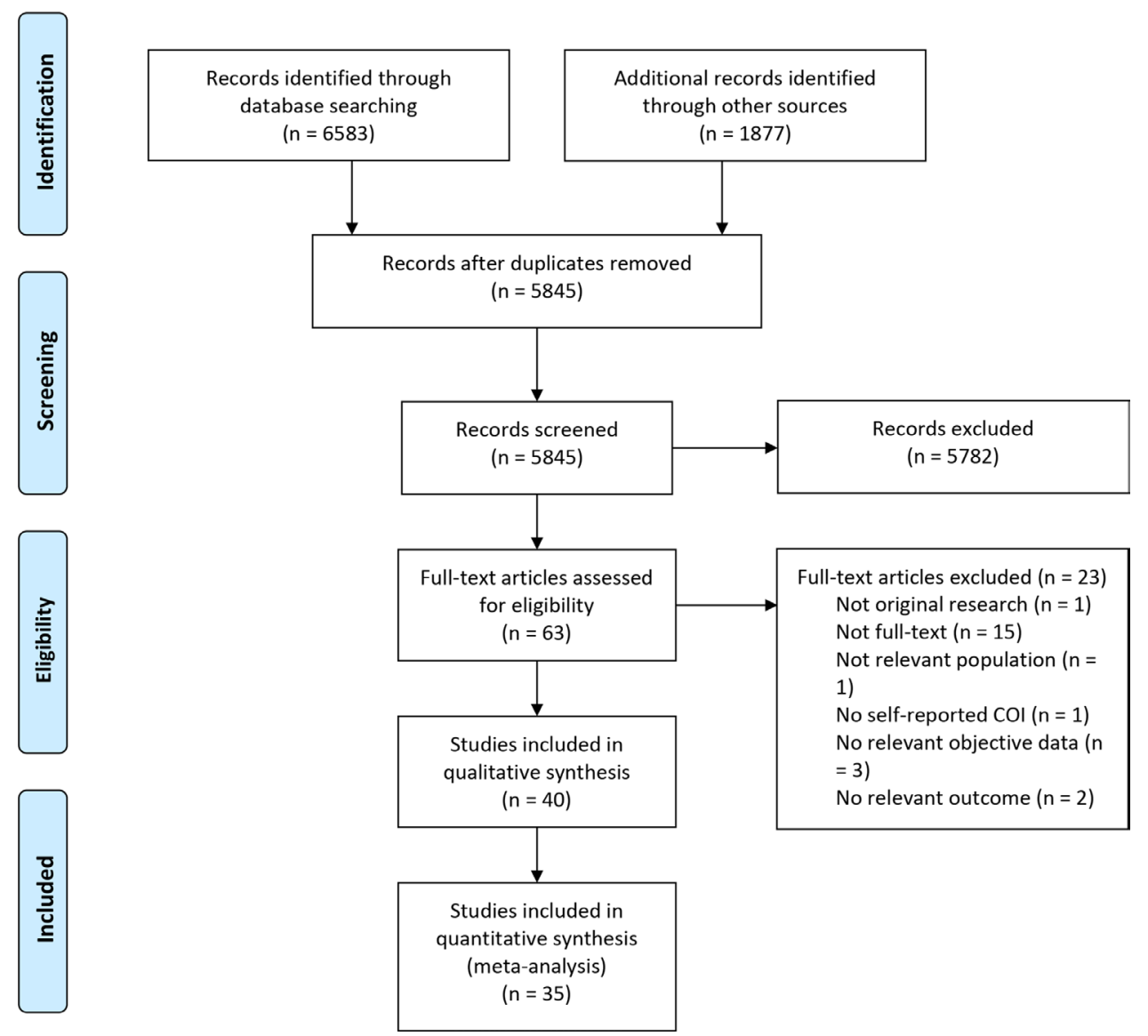

Figure 1 Preferred Reporting Items for Systematic Reviews and Meta-analysis flow diagram. COI, conflicts of interest.

examined self-reported disclosures by physician authors or presenters of academic work; three studies also reported disclosures by conference organisers. ${ }^{112526}$ Most studies examined disclosures of physicians conducting work within a common discipline; four examined disclosures of physicians across a variety of disciplines. ${ }^{12} 223941$ Disclosures in surgical disciplines were most commonly investigated; eight studies focused on disclosures of physicians working in orthopaedic surgery, ${ }^{11} 13404245484956$ three of those working in plastic surgery, ${ }^{14} 4453$ two of those working in otolaryngology, ${ }^{25} 31$ two of those working in $\operatorname{urology}^{3455}$ and three of those working in other surgical specialties. ${ }^{26} 4750$ Aside from one which used data from the US department of Justice investigations, ${ }^{39}$ all studies used industry-reported payment data as the objective comparison; of these 39 studies reliant on industry-reported payment data, 30 examined data from the Centers for Medicare and Medicaid Services' Open Payments Database, ${ }^{12} 14$ 25-27 29-37 40-47 49-53 55-57 two studies used the ProPublica's Dollars for Docs database, ${ }^{28} 38$ two studies used both of these sources, ${ }^{25} 54$ two studies used the Danish Health and Medicines Authority's public disclosure list ${ }^{22} 23$ and three studies referenced the web pages of device manufacturers. ${ }^{11} 1348$ All included studies examined different data sets except two ${ }^{1148}$ both of which examined the same data set involving five manufacturers of total hip and knee prosthesis in 2007. Most studies examined COI involving relatively recent financial relationships; one study ${ }^{39}$ examined relationships dating back to 1999 . Two studies ${ }^{51}{ }^{52}$ did not specify the time period studied.

\section{Proportion of COI discrepant}

As outlined above the included studies examined COI involving articles, authors, authorships and payments. The majority of studies defined discrepancies as one or more undisclosed COI, but three studies considered a discrepancy to occur only when all COI were inaccurately disclosed by an author. ${ }^{38} 4956$

An exploratory meta-analysis was attempted to summarise the studies that examined the accuracy of self-reported financial COI at the article, payment, authorship and author level. However, heterogeneity of pooled data was high across all four levels examined with $\mathrm{I}^{2}=94 \%-99 \%$. For completeness, we have reported the results of this analysis in online supplemental appendix 2 . The pooled proportion of the 10 studies (1583 total articles pooled) reporting discrepancies at the article level was $81 \%$ (range: $54 \%-98 \%$; $95 \%$ CI $72 \%$ to $89 \%$ ) (online supplemental appendix 2A). The pooled proportion of the three studies (1958 total payments pooled) reporting discrepancies at the payment level was $79 \%$ (range: $71 \%-89 \%$; 95\% CI $67 \%$ to $89 \%$ ) (online supplemental appendix 2B). The pooled proportion of the four studies (907 total authorships pooled) reporting discrepancy at the authorship level was 93\% (range: $71 \%-100 \%$; 
Table 2 Characteristics of included studies

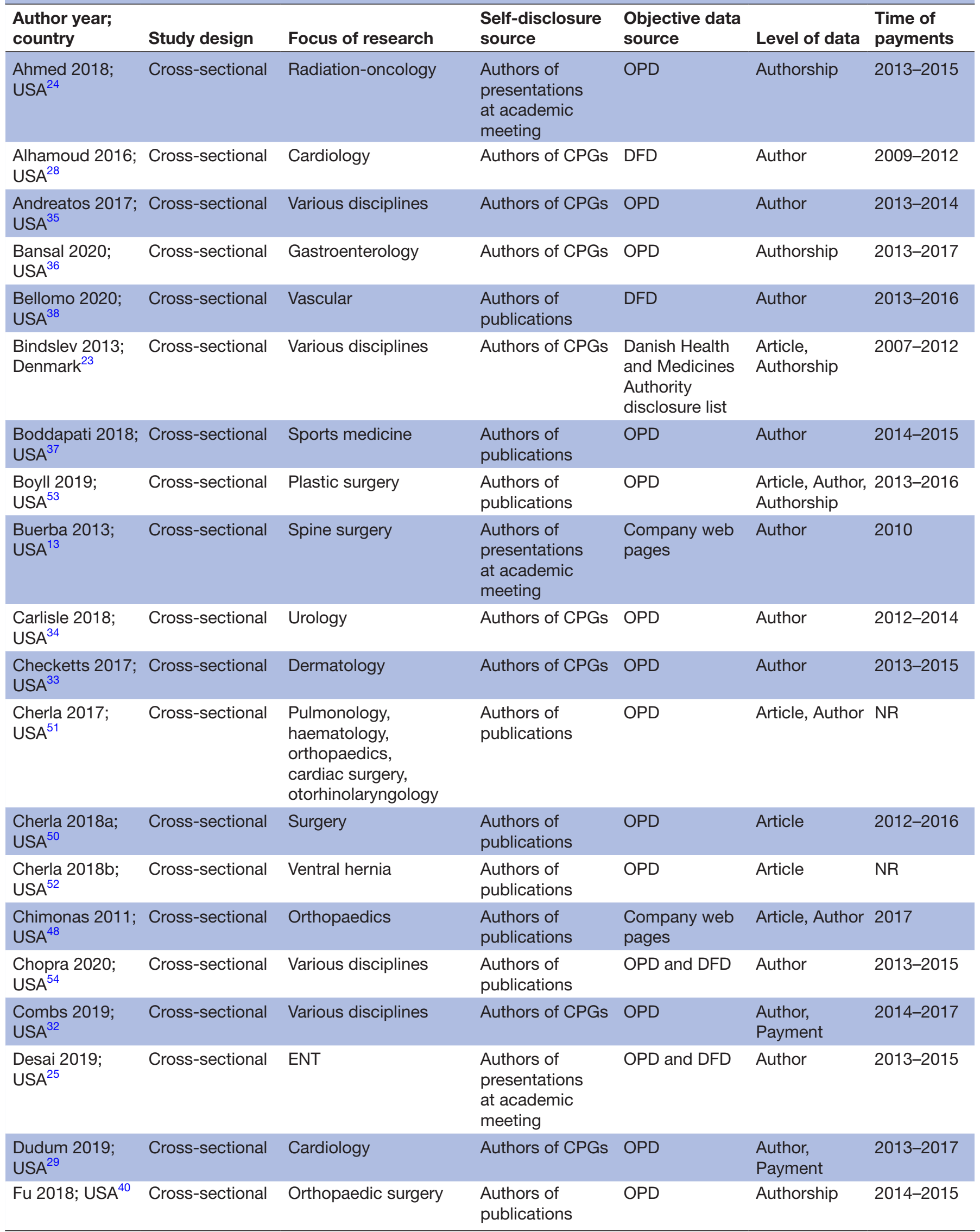


Table 2 Continued

\begin{tabular}{|c|c|c|c|c|c|c|}
\hline $\begin{array}{l}\text { Author year; } \\
\text { country }\end{array}$ & Study design & Focus of research & $\begin{array}{l}\text { Self-disclosure } \\
\text { source }\end{array}$ & $\begin{array}{l}\text { Objective data } \\
\text { source }\end{array}$ & Level of data & $\begin{array}{l}\text { Time of } \\
\text { payments }\end{array}$ \\
\hline $\begin{array}{l}\text { Garrett-Mayer } \\
\text { 2020; USA }{ }^{57}\end{array}$ & Cross-sectional & Oncology & $\begin{array}{l}\text { Authors of } \\
\text { presentations } \\
\text { at academic } \\
\text { meeting and } \\
\text { publications }\end{array}$ & OPD & Author & 2016-2017 \\
\hline $\begin{array}{l}\text { Horn 2018; } \\
\text { USA }^{31}\end{array}$ & Cross-sectional & Otolaryngology & Authors of CPGs & OPD & Author & 2013-2016 \\
\hline $\begin{array}{l}\text { Hughes 2019; } \\
\text { USA }^{56}\end{array}$ & Cross-sectional & $\begin{array}{l}\text { Orthopaedic surgery/ } \\
\text { sports medicine }\end{array}$ & $\begin{array}{l}\text { Authors of } \\
\text { presentations } \\
\text { at academic } \\
\text { meeting }\end{array}$ & OPD & Author & 2015 \\
\hline $\begin{array}{l}\text { Janney 2019; } \\
\text { USA }^{49}\end{array}$ & Cross-sectional & Orthopaedic surgery & $\begin{array}{l}\text { Authors of } \\
\text { publications }\end{array}$ & OPD & Authorship & 2013-2016 \\
\hline $\begin{array}{l}\text { Jimbo 2019; } \\
\text { USA }\end{array}$ & Cross-sectional & Urology & $\begin{array}{l}\text { Authors of } \\
\text { publications }\end{array}$ & OPD & Article, Author & 2013-2016 \\
\hline $\begin{array}{l}\text { Kesselheim } \\
\text { 2012; USA }{ }^{39}\end{array}$ & Cross-sectional & Various disciplines & $\begin{array}{l}\text { Authors of } \\
\text { publications }\end{array}$ & $\begin{array}{l}\text { United States } \\
\text { Department } \\
\text { of Justice } \\
\text { investigations }\end{array}$ & Article, Author & 1999-2007 \\
\hline $\begin{array}{l}\text { Lois 2019; } \\
\text { USA }^{27}\end{array}$ & Cross-sectional & Gastroenterology & $\begin{array}{l}\text { Authors of } \\
\text { presentations } \\
\text { at academic } \\
\text { meeting }\end{array}$ & OPD & Author & 2017 \\
\hline $\begin{array}{l}\text { Lopez 2018; } \\
\text { USA }^{14}\end{array}$ & Cross-sectional & Plastic surgery & $\begin{array}{l}\text { Authors of } \\
\text { publications }\end{array}$ & OPD & Author & 2013 \\
\hline $\begin{array}{l}\text { Luce 2017; } \\
\text { USA }^{44}\end{array}$ & Cross-sectional & Plastic surgery & $\begin{array}{l}\text { Authors of } \\
\text { publications }\end{array}$ & OPD & Article & 2015 \\
\hline $\begin{array}{l}\text { Norris 2012; } \\
\text { USA }^{12}\end{array}$ & Cross-sectional & Various disciplines & $\begin{array}{l}\text { Authors of } \\
\text { publications }\end{array}$ & DFD & Article & 2009-2010 \\
\hline $\begin{array}{l}\text { Okike 2009; } \\
\text { USA }^{11}\end{array}$ & Cross-sectional & Orthopaedic surgery & $\begin{array}{l}\text { Authors of } \\
\text { presentations } \\
\text { at academic } \\
\text { meeting }\end{array}$ & $\begin{array}{l}\text { Company web } \\
\text { pages }\end{array}$ & Payment & 2007 \\
\hline $\begin{array}{l}\text { Olavarria 2017; } \\
\text { USA }^{43}\end{array}$ & Cross-sectional & Ventral hernias & $\begin{array}{l}\text { Authors of } \\
\text { publications }\end{array}$ & OPD & Article, Author & 2012-2014 \\
\hline $\begin{array}{l}\text { Patel 2018; } \\
\text { USA }^{47}\end{array}$ & Cross-sectional & Robotic surgery & $\begin{array}{l}\text { Authors of } \\
\text { publications }\end{array}$ & OPD & Article, Author & 2013-2014 \\
\hline $\begin{array}{l}\text { Rasmussen } \\
\text { 2015; Denmark }{ }^{22}\end{array}$ & Cross-sectional & Various disciplines & $\begin{array}{l}\text { Authors of } \\
\text { publications }\end{array}$ & $\begin{array}{l}\text { Danish Health } \\
\text { and } \\
\text { Medicines } \\
\text { Authority's } \\
\text { public } \\
\text { disclosure list }\end{array}$ & Author & 2010-2013 \\
\hline $\begin{array}{l}\text { Ross 2020; } \\
\text { USA }^{42}\end{array}$ & Cross-sectional & Hand surgery & $\begin{array}{l}\text { Authors of } \\
\text { publications }\end{array}$ & OPD & $\begin{array}{l}\text { Author, } \\
\text { Authorship }\end{array}$ & 2014-2016 \\
\hline $\begin{array}{l}\text { Saleh 2019; } \\
\text { USA }^{30}\end{array}$ & Cross-sectional & Oncology & Authors of CPGs & OPD & Author & 2013-2017 \\
\hline $\begin{array}{l}\text { Somerson 2020; } \\
\text { USA }\end{array}$ & Cross-sectional & Orthopaedic surgery & $\begin{array}{l}\text { Authors of } \\
\text { publications }\end{array}$ & OPD & Authorship & 2015-2016 \\
\hline Tau 2019; USA ${ }^{41}$ & Cross-sectional & Various disciplines & $\begin{array}{l}\text { Authors of } \\
\text { publications }\end{array}$ & OPD & Author & 2013-2015 \\
\hline
\end{tabular}

Continued 
Table 2 Continued

\begin{tabular}{|c|c|c|c|c|c|c|}
\hline $\begin{array}{l}\text { Author year; } \\
\text { country }\end{array}$ & Study design & Focus of research & $\begin{array}{l}\text { Self-disclosure } \\
\text { source }\end{array}$ & $\begin{array}{l}\text { Objective data } \\
\text { source }\end{array}$ & Level of data & $\begin{array}{l}\text { Time of } \\
\text { payments }\end{array}$ \\
\hline $\begin{array}{l}\text { Thompson } 2016 \\
\text { USA }^{26}\end{array}$ & Cross-sectional & Obstetrics/Gynaecology & $\begin{array}{l}\text { Authors of } \\
\text { presentations } \\
\text { at academic } \\
\text { meeting }\end{array}$ & OPD & Author & 2014 \\
\hline Yee 2015; USA ${ }^{46}$ & Cross-sectional & Ophthalmology & $\begin{array}{l}\text { Authors of } \\
\text { publications }\end{array}$ & OPD & $\begin{array}{l}\text { Authorship, } \\
\text { Payment }\end{array}$ & 2013 \\
\hline
\end{tabular}

CPG, Clinical Practice Guideline; DFD, Dollars For Docs (ProPublica); NR, not reported; OPD, Open Payments Database (Centers for Medicare and Medicaid Services).

95\% CI $79 \%$ to $100 \%$ ) (online supplemental appendix 2C). The pooled proportion of the 23 studies (5984 total authors pooled) reporting discrepancy at the author level was $66 \%$ (range: $8 \%-99 \%$; $95 \%$ CI $48 \%$ to $78 \%$ ) (online supplemental appendix 2D).

\section{Relevance of discrepant COI}

Nine studies reported the proportion of relevant discrepancies. ${ }^{811} 14222636424450$ Discrepancies were reported as being considered relevant if the payments provided were directly, or indirectly, related to the topic of the presentation, clinical practice guidelines or another publication. Because only nine studies reported these data, and each had examined discrepancies at a different level, we elected to not pool this outcome. The proportion of relevant discrepancies ranges from $6 \%$ to $99 \%$. The median proportion of relevant discrepancies is $45 \%$. There is considerable heterogeneity across studies.

\section{Proportion of funds discrepant}

Nine studies reported the proportion of total amounts which were discrepantly reported. However, similar to the proportion of COI discrepant, there was high heterogeneity between studies $\left(\mathrm{I}^{2}=100 \%\right)$. The exploratory analysis that pools the proportion of nine studies (US\$70 930311 total funds pooled) reporting funding discrepancies are reported in online supplemental appendix 3 . The pooled proportion of total amounts which were discrepant was $33 \%$ (range: $2 \%-77 \%$; $95 \%$ CI $12 \%$ to $58 \%$ ).

\section{Types of discrepant COI}

Specific types of financial COI were reported as undisclosed in nine studies. These were similar across studies. ${ }^{24} 2930333637404557$ The most common category of undisclosed COI was general payments. According to the payment databases, general payments include food and beverage, travel and lodging, consulting, royalties and licenses, non-consulting services (including serving as faculty or speaker at an event other than continuing education), payments for education, speaker and faculty fees, and honoraria. ${ }^{29} 3637404557$ Within this category, food and beverage were identified by three studies as among the most frequently undisclosed. ${ }^{40} 457$ Two studies identified travel and lodging, ${ }^{4057}$ two identified consulting and speaking, ${ }^{24} 29$ and one identified non-consulting services (including serving as faculty or speaker at an event other than continuing education) as the most commonly undisclosed. ${ }^{29}$ Two studies identified research payments as the most commonly undisclosed, ${ }^{24}{ }^{30}$ and another two studies identified them as commonly undisclosed. ${ }^{36} 37$

\section{Factors associated with discrepancies}

A total of 15 out of 40 studies reported factors that are associated with discrepant reporting. ${ }^{11} 1314242835-37394247-495153$ We conducted a narrative summary of these factors. Table 3 summarises the results of each study reporting factors that were associated with discrepant reporting of financial COIs. We organised factors into four themes: factors related to author characteristics (eg, academic affiliation), payment characteristics (eg, amount of payment from industry), article characteristics (eg, level/hierarchy of evidence, such as systematic review vs commentary) and journal characteristics (eg, impact factor). Of these, author and payment characteristics were the most commonly reported factors that were associated with discrepant reporting.

Three studies examined the influence of an author's gender in discrepant reporting. ${ }^{24} 3637$ There were no consistent results across studies regarding the outcomes. Six studies examined whether the position of an author on a scientific article influenced discrepant reporting. ${ }^{36} 3739424853$ The data concerning author position was also conflicting. Some studies found that prominent (first, last or sole) authors were associated with discrepant reporting, while other studies found that other (middle) authors were associated with discrepant reporting. Two studies reported no association across authorship positions. ${ }^{36} 39$

Other author-related factors include an affiliation with an academic institution, the physician specialty and physician role at an academic meeting (eg, organiser vs attendee). Two studies identified the influence of author affiliations on undisclosed payments ${ }^{1436}$; both reported that authors with academic affiliation were significantly more likely to have undisclosed payments compared with those without. One study reported that physician's roles are associated with reporting behaviour. ${ }^{11}$ At one academic meeting, physicians who did not serve as board members or committee members, or who were not 
Table 3 Results of studies investigating factors associated with discrepant reporting

\begin{tabular}{ll}
\hline Study & Factors evaluated \\
\hline Ahmed $2018^{24}$ & At least one disclosure* \\
& $\begin{array}{l}\text { Duration of presentation } \\
\text { Sex }\end{array}$ \\
& $\begin{array}{l}\text { Word count } \\
\text { Year of presentation } \\
\text { Words per second } \\
\text { (spoken during } \\
\text { presentation) }\end{array}$ \\
Alhamoud $2016^{28}$ & Payment amount
\end{tabular}

\section{Significant results}

On univariable analysis, having at least one disclosure (OR 2.62; 95\% Cl 1.02 to 5.24 ) and male sex (OR 3.76; $95 \% \mathrm{Cl} 1.45$ to 12.8 ) were associated with having a discrepancy. On multivariable regression, only the number of words per second was correlated to having a discrepancy (OR 1.08; 95\% Cl 1.01 to 1.80).

\begin{tabular}{|c|c|c|}
\hline Andreatos $2017^{35}$ & $\begin{array}{l}\text { Specialty* } \\
\text { Type of payment } \\
\text { Total payment value }\end{array}$ & $\begin{array}{l}\text { Authors of general medicine }(p=0.02) \text {, orthopaedics/ trauma }(p=0.01) \text {, } \\
\text { pulmonology }(p=0.02) \text {, gastroenterology }(p=0.02) \text {, and radiology }(p=0.03) \\
\text { guidelines had significantly less accurate COI disclosures compared with } \\
\text { other specialties. Authors were significantly less likely to inaccurately report } \\
\text { 'research payments' compared with 'general payments' }(75.5 \% \text { vs } 87.3 \% \text {; } \\
p=0.02) \text {. }\end{array}$ \\
\hline Bansal $2020^{36}$ & $\begin{array}{l}\text { Sex }^{*} \\
\text { Academic affiliation* } \\
\text { Authorship order }\end{array}$ & $\begin{array}{l}\text { Male authors (OR } 2.23 ; 95 \% \mathrm{Cl} 1.47 \text { to } 3.39 \text { ) and academically affiliated } \\
\text { authors (OR } 8.87 ; 95 \% \mathrm{Cl} 5.57 \text { to } 14.13 \text { ) were significantly more likely to have } \\
\text { undeclared payments ( } \mathrm{p}<0.001) \text {. }\end{array}$ \\
\hline Boddapati $2018^{37}$ & $\begin{array}{l}\text { Payment amount* } \\
\text { Authorship order* } \\
\text { Sex* } \\
\text { Level of evidence* } \\
\text { Type of payment* }\end{array}$ & $\begin{array}{l}\text { Authors with total payments }>\text { US } \$ 500000 \text { were less likely to be discrepant } \\
\text { than those earning }<\text { US } \$ 10000(16.1 \% \text { vs } 85.3 \% ; p<0.001) \text {. First authors } \\
\text { had a lower percentage of payment values with discrepancy versus } \\
\text { middle authors }(13.8 \% \text { vs } 31.9 \% ; p=0.001) \text {. Men had a lower percentage } \\
\text { of payment values with discrepancy as compared with women ( } 22.3 \% \text { vs } \\
95.3 \% ; p<0.001) \text {. The discrepancy rate was lowest in the level of evidence } \\
\text { one subgroup as compared with the other groups, such as level of evidence } \\
2(75.0 \% \text { vs } 90.3 \% ; p=0.013) \text {. Authors were least discrepant in general } \\
\text { payments compared with research and ownership payments ( } 17.2 \% \text { vs } \\
32.7 \% \text { vs } 47.5 \% ; p<0.001) \text {. }\end{array}$ \\
\hline Boyll $2019^{53}$ & Authorship order* & $\begin{array}{l}\text { A middle author is less likely to have discrepancies than the first or last } \\
\text { author (OR, 3.593; } 95 \% \mathrm{Cl} 1.211 \text { to } 10.657 ; \mathrm{p}=0.0212) \text {. }\end{array}$ \\
\hline Buerba $2013^{13}$ & Payment amount ${ }^{*}$ & $\begin{array}{l}\text { Those who received payments }<\text { US } \$ 100000 \text { from Medtronic were more likely } \\
\text { to have discrepancies in their disclosures than those who received payments } \\
>\text { US } \$ 100000(p=0.009) \text {. }\end{array}$ \\
\hline Cherla $2017^{51}$ & Specialty* & $\begin{array}{l}\text { Between the medical and surgical published literature, the discordance } \\
\text { rate for manuscripts differed significantly }(71.5 \% \text { vs } 60.7 \% ; p=0.01) \text {. } \\
\text { Haematology manuscripts exhibited the highest incomplete disclosure rate } \\
\text { while otorhinolaryngology manuscripts showed the lowest ( } 75.0 \% \text { vs } 42.0 \% \text {; } \\
p<0.001) \text {. }\end{array}$ \\
\hline Chimonas $2011^{48}$ & $\begin{array}{l}\text { Authorship order* } \\
\text { Payment relatedness* } \\
\text { Journal policy }\end{array}$ & $\begin{array}{l}\text { First, sole or senior authors were more likely to disclose than middle authors } \\
(54 \% \text { vs } 32 \% ; p=0.03) \text {. Articles related to company payments were more } \\
\text { likely to disclose compared with unrelated payments ( } 50 \% \text { vs } 11 \% ; p=0.04) \text {. }\end{array}$ \\
\hline Janney $2019^{49}$ & Year of publication & $\mathrm{N} / \mathrm{A}$ \\
\hline Kesselheim $2012^{39}$ & $\begin{array}{l}\text { Type of article } \\
\text { Specialty } \\
\text { Authorship order } \\
\text { Journal impact factor } \\
\text { Article citation index }\end{array}$ & $\begin{array}{l}\text { The researchers found that commentaries were significantly less likely to have } \\
\text { adequate disclosure compared with articles reporting studies or trials (OR } \\
0.10 ; 95 \% \mathrm{Cl} 0.02 \text { to } 0.67 ; p=0.02 \text { ). }\end{array}$ \\
\hline Lopez $2018^{14}$ & $\begin{array}{l}\text { Academic affiliation }{ }^{\star} \\
\text { Payment relatedness }^{\star} \\
\text { Payment amount }^{\star}\end{array}$ & $\begin{array}{l}\text { Non-academic authors were } 6.25 \text { times more likely to disclose COI compared } \\
\text { with authors with an academic affiliation }(p<0.0001) \text {. Authors who received } \\
\text { US } \$ 500 \text { or more in transactions of value were } 9.09 \text { times more likely to } \\
\text { disclose COI compared with authors who received less than US } \$ 200 \\
\text { ( } p<0.0001) \text {. Authors whose COI was related to the topic of their article were } \\
2.75 \text { times more likely to disclose conflicts of interest compared with authors } \\
\text { whose COI was unrelated to the topic of their article }(p<0.0001) \text {. }\end{array}$ \\
\hline
\end{tabular}

Payments $\geq$ US $\$ 10000$ were 2.8 times more likely to be reported than modest or no payments $(\mathrm{p}=0.001)$ pulmonology $(p=0.02)$, gastroenterology $(p=0.02)$, and radiology $(p=0.03)$ guidelines had significantly less accurate $\mathrm{COI}$ disclosures compared with other specialties. Authors were significantly less likely to inaccurately report 'research payments' compared with 'general payments' $(75.5 \%$ vs $87.3 \%$; 


\begin{tabular}{|c|c|c|}
\hline Study & Factors evaluated & Significant results \\
\hline Okike $2009^{11}$ & $\begin{array}{l}\text { Payment amount* } \\
\text { Payment made to an } \\
\text { individual physician } \\
\text { Payment with in-kind } \\
\text { component }^{\star} \\
\text { Physician role* } \\
\text { Payment relatedness }\end{array}$ & $\begin{array}{l}\text { Payments were more likely to have been disclosed if they exceeded US } \$ 10 \\
000 \text { than if they did not }(64.4 \% \text { vs } 42.9 \% ; p<0.001) \text {, were directed towards an } \\
\text { individual physician rather than a company or organisation }(78.1 \% \text { vs } 45.9 \% \text {; } \\
p=0.04) \text { or included an in-kind component }(79.0 \% \text { vs } 46.3 \% ; p=0.002) \text {. } \\
\text { Members of the board of directors or annual-meeting committees were more } \\
\text { likely to disclose payments than others }(86.0 \% \text { vs } 69.1 \% ; p=0.009) \text {, and so } \\
\text { were symposium presenters or instructional-course lecturers }(87.0 \text { vs } 58.4 \% \text {; } \\
p<0.001) \text {. Directly related payments were more likely to be disclosed than } \\
\text { unrelated payments }(79.3 \% \text { vs } 49.2 \% ; p=0.008) \text {. }\end{array}$ \\
\hline Patel $2018^{47}$ & $\begin{array}{l}\text { Study type } \\
\text { Impact factor } \\
\text { Specialty* }\end{array}$ & $\begin{array}{l}\text { 'Other' surgical subspecialties (including cardiothoracic surgery, head and } \\
\text { neck, neurosurgery, vascular surgery) were less likely to have discrepancies } \\
\text { than general surgery (OR } 0.61 ; 95 \% \mathrm{Cl} 0.38 \text { to } 1.00 ; \mathrm{p}=0.01 \text { ). }\end{array}$ \\
\hline Ross $2020^{42}$ & Authorship order* & $\begin{array}{l}\text { Authors listed last on a paper were found to have significantly more } \\
\text { undeclared payments than first and middle authors ( } 77 \% \text { vs } 47 \% \text { vs } 51 \% \text {; } \\
p<0.0001 \text { ). }\end{array}$ \\
\hline
\end{tabular}

${ }^{*}$ Factor was significantly associated with nondisclosure.

COI, conflicts of interest; N/A, not available.

symposium presenters or instructional-course lecturers at the meeting were less likely to disclose. Four studies reported the associations between physician specialty and discrepant reporting. ${ }^{35} 39451$ Three of these studies found an association ${ }^{35} 47$; ; one found no difference among specialties. ${ }^{39}$ Patel et $a l^{47}$ reported that general surgeons were more likely to have discrepant reporting than those in other surgical specialties. Cherla et $a e^{51}$ found that manuscripts related to haematology exhibited the highest discrepant reporting, while manuscripts related to otolaryngology were associated with the lowest rates. Andreatos $e t a l^{35}$ reported that authors of guidelines in general medicine, orthopaedics, trauma, pulmonology, gastroenterology and radiology had significantly higher rates of discrepant reporting than did authors of guidelines in other specialties.

Six studies reported on the association of the value of payments that were not disclosed. ${ }^{11} 1314283537$ Five found that authors who received smaller total payments or individual payments of lesser value were associated with discrepant reporting ${ }^{11} 13142837$ Studies differed in what was reported to be considered 'significant' amounts, from US $\$ 500,{ }^{14}$ US $\$ 10 \quad 000,{ }^{11} 28$ US $\$ 100 \quad 000^{11} 13$ to US $\$ 500000 .{ }^{37}$ The sixth study was the only one to report no statistically significant association between discrepant reporting and the value of the payments involved. ${ }^{35}$

Five studies commented on other payment-related factors. ${ }^{11} 14353748$ One study found that payments made to a group or organisation were more likely to be undisclosed when compared with payments made to an individual physician. ${ }^{11}$ Additionally, when payments did not include an in-kind component they were less likely to be reported. ${ }^{11}$ Payments that were unrelated to the topic of the presentation or article were more likely to be undisclosed than directly or indirectly related payments. $^{11} 1448$ However, not all payment types were equally likely to be unreported. 'General payments' (such as food and beverage, travel and lodging) were more likely to be incompletely or inaccurately reported than 'research payments'. 35

Three studies commented on article-level factors associated with discrepancies. ${ }^{37} 3947$ One study found that when stratified by the level of evidence, authors of papers of higher levels of evidence (level of evidence $\geq 1$ ) were significantly more likely to have discrepancies than those authors of papers of lower levels of evidence. ${ }^{37} 39$ Another study found that there was no difference between comparative (observational studies, randomised controlled studies or meta-analyses/systematic reviews) and noncomparative studies (case series, technique description or editorials/comments). ${ }^{47}$ Additionally, article citation index per year since publication was not associated with disclosure. $^{39}$

Three studies described the association of journal characteristics with discrepant reporting. ${ }^{39} 4748$ Two studies found no statistically significant association with journal impact factor. ${ }^{39}$ Moreover, one study found that the accuracy of disclosures did not vary with the strength of journals' disclosure policies, and there was no association between a journal's endorsement of specific International Committee of Medical Journal Editors (ICMJE) policy recommendations and discrepant reporting. ${ }^{48}$

\section{Reported explanation for discrepant COI}

One study investigated explanations for nondisclosure by administering a survey to physicians who had not fully disclosed COI in the final programme of an annual meeting, ${ }^{11}$ with a response rate of $39.6 \%$ (36/91). The most common explanations for nondisclosure were that payments were considered unrelated to the topic of the presentation $(39 \% ; 14$ of 36$)$, or that disclosure requirements were misunderstood $(14 \% ; 5$ of 36$)$. Other 


\begin{tabular}{|l|c|c|c|c|c|c|c|c|}
\hline \multirow{2}{*}{\multicolumn{1}{|c|}{ Study }} & \multicolumn{7}{|c|}{ Checklist Item* } \\
\cline { 2 - 8 } & $\mathbf{1}$ & $\mathbf{2}$ & $\mathbf{3}$ & $\mathbf{4}$ & $\mathbf{5}$ & $\mathbf{6}$ & $\mathbf{7}$ & $\mathbf{8}$ \\
\hline Ahmed 2018 & $\odot$ & $\odot$ & $\odot$ & $\odot$ & $\odot$ & $\odot$ & $\odot$ & $\odot$ \\
\hline Alhamoud 2016 & $\odot$ & $\odot$ & $\odot$ & $\odot$ & $\odot$ & $\odot$ & $\odot$ & $\odot$ \\
\hline Andreatos 2017 & $\odot$ & $\odot$ & $\odot$ & $\odot$ & $\odot$ & $\odot$ & $\odot$ & $\odot$ \\
\hline Bansal 2020 & $\odot$ & $\odot$ & $\odot$ & $\odot$ & $\odot$ & $\odot$ & $\odot$ & $\odot$ \\
\hline Bellomo 2020 & $\odot$ & $\odot$ & $\odot$ & $\odot$ & $\odot$ & $\odot$ & $\odot$ & $\odot$ \\
\hline Bindslev 2013 & $\odot$ & $\odot$ & $\odot$ & $\odot$ & $\odot$ & $\odot$ & $\odot$ & $\odot$ \\
\hline Boddapati 2018 & $\odot$ & $\odot$ & $\odot$ & $\odot$ & $\odot$ & $\odot$ & $\odot$ & $\odot$ \\
\hline Boyll 2019 & $\odot$ & $\odot$ & $\odot$ & $\odot$ & $\odot$ & $\odot$ & $\odot$ & $\odot$ \\
\hline Buerba 2013 & $\odot$ & $\odot$ & $\odot$ & $\odot$ & $\odot$ & $\odot$ & $\odot$ & $\odot$ \\
\hline Carlisle 2018 & $\odot$ & $\odot$ & $\odot$ & $\odot$ & $\odot$ & $\odot$ & $\odot$ & $\odot$ \\
\hline Checketts 2017 & $\odot$ & $\odot$ & $\odot$ & $\odot$ & $\odot$ & $\odot$ & $\odot$ & $\odot$ \\
\hline Cherla 2017 & $\odot$ & $\odot$ & $\odot$ & $\odot$ & $\odot$ & $\odot$ & $\odot$ & $\odot$ \\
\hline Cherla 2018a & $\odot$ & $\odot$ & $\odot$ & $\odot$ & $\odot$ & $\odot$ & $\odot$ & $\odot$ \\
\hline Cherla 2018b & $\odot$ & $\odot$ & $\odot$ & $\odot$ & $\odot$ & $\odot$ & $\odot$ & $\odot$ \\
\hline Chimonas 2011 & $\odot$ & $\odot$ & $\odot$ & $\odot$ & $\odot$ & $\odot$ & $\odot$ & $\odot$ \\
\hline Chopra 2020 & $\odot$ & $\odot$ & $\odot$ & $\odot$ & $\odot$ & $\odot$ & $\odot$ & $\odot$ \\
\hline Combs 2019 & $\odot$ & $\odot$ & $\odot$ & $\odot$ & $\odot$ & $\odot$ & $\odot$ & $\odot$ \\
\hline Desai 2019 & $\odot$ & $\odot$ & $\odot$ & $\odot$ & $\odot$ & $\odot$ & $\odot$ & $\odot$ \\
\hline Dudum 2019 & $\odot$ & $\odot$ & $\odot$ & $\odot$ & $\odot$ & $\odot$ & $\odot$ & $\odot$ \\
\hline
\end{tabular}

\begin{tabular}{|l|c|c|c|c|c|c|c|c|}
\hline Fu 2018 & $\odot$ & $\odot$ & $\odot$ & $\odot$ & $\odot$ & $\odot$ & $\odot$ & $\odot$ \\
\hline Garrett-Mayer 2020 & $\odot$ & $\odot$ & $\odot$ & $\odot$ & $\odot$ & $\odot$ & $\odot$ & $\odot$ \\
\hline Horn 2018 & $\odot$ & $\odot$ & $\odot$ & $\odot$ & $\odot$ & $\odot$ & $\odot$ & $\odot$ \\
\hline Hughes 2019 & $\odot$ & $\odot$ & $\odot$ & $\odot$ & $\odot$ & $\odot$ & $\odot$ & $\odot$ \\
\hline Janney 2019 & $\odot$ & $\odot$ & $\odot$ & $\odot$ & $\odot$ & $\odot$ & $\odot$ & $\odot$ \\
\hline Jimbo 2019 & $\odot$ & $\odot$ & $\odot$ & $\odot$ & $\odot$ & $\odot$ & $\odot$ & $\odot$ \\
\hline Kesselheim 2012 & $\odot$ & $\odot$ & $\odot$ & $\odot$ & $\odot$ & $\odot$ & $\odot$ & $\odot$ \\
\hline Lois 2019 & $\odot$ & $\odot$ & $\odot$ & $\odot$ & $\odot$ & $\odot$ & $\odot$ & $\odot$ \\
\hline Lopez 2018 & $\odot$ & $\odot$ & $\odot$ & $\odot$ & $\odot$ & $\odot$ & $\odot$ & $\odot$ \\
\hline Luce 2017 & $\odot$ & $\odot$ & $\odot$ & $\odot$ & $\odot$ & $\odot$ & $\odot$ & $\odot$ \\
\hline Norris 2012 & $\odot$ & $\odot$ & $\odot$ & $\odot$ & $\odot$ & $\odot$ & $\odot$ & $\odot$ \\
\hline Okike 2009 & $\odot$ & $\odot$ & $\odot$ & $\odot$ & $\odot$ & $\odot$ & $\odot$ & $\odot$ \\
\hline Olavarria 2017 & $\odot$ & $\odot$ & $\odot$ & $\odot$ & $\odot$ & $\odot$ & $\odot$ & $\odot$ \\
\hline Patel 2018 & $\odot$ & $\odot$ & $\odot$ & $\odot$ & $\odot$ & $\odot$ & $\odot$ & $\odot$ \\
\hline Rasmussen 2015 & $\odot$ & $\odot$ & $\odot$ & $\odot$ & $\odot$ & $\odot$ & $\odot$ & $\odot$ \\
\hline Ross 2020 & $\odot$ & $\odot$ & $\odot$ & $\odot$ & $\odot$ & $\odot$ & $\odot$ & $\odot$ \\
\hline Saleh 2019 & $\odot$ & $\odot$ & $\odot$ & $\odot$ & $\odot$ & $\odot$ & $\odot$ & $\odot$ \\
\hline Somerson 2020 & $\odot$ & $\odot$ & $\odot$ & $\odot$ & $\odot$ & $\odot$ & $\odot$ & $\odot$ \\
\hline Tau 2019 & $\odot$ & $\odot$ & $\odot$ & $\odot$ & $\odot$ & $\odot$ & $\odot$ & $\odot$ \\
\hline Thompson 2016 & $\odot$ & $\odot$ & $\odot$ & $\odot$ & $\odot$ & $\odot$ & $\odot$ & $\odot$ \\
\hline Yee 2015 & $\odot$ & $\odot$ & $\odot$ & $\odot$ & $\odot$ & $\odot$ & $\odot$ & $\odot$ \\
\hline
\end{tabular}

Figure 2 Risk-of-bias assessment of included studies using a modified Joanna Briggs Institute Critical Appraisal Checklist for studies reporting prevalence data. ${ }^{*} 1$. Was the sample frame appropriate to address the target population? 2 . Were study participants sampled in an appropriate way? 3 . Was the sample size adequate? 4 . Were the syudy subjects and the setting described in detail? 5. Was the data analysis conducted with sufficient coverage of the identified sample? 6 . Were valid methods used for the identification of the objective payment data? 7. Were measurements conducted a standard, reliable way for all participants? 8. Was there appropriate statistical analysis?

explanations included that the payment was disclosed, but mistakenly omitted from the annual-meeting programme $(11 \% ; 4$ of 36$)$, that the disclosure process was handled by a coauthor who failed to communicate disclosure requirements $(8 \% ; 3$ of 36$)$, or that the payment was unintentionally omitted from the disclosure statement (6\%; 2 of 36). Another 3\% (1 of 36) reported that the payment from industry was not large enough to be disclosed.

\section{Relationship between discrepant COI and study outcomes}

Data concerning the association of unreported COI and research outcome were reported by three studies, but the results are conflicting. ${ }^{475052}$ One study found that studies with discrepancies between declared COI and actual COI were more likely to report positive outcomes when compared with those that had no discrepancies, even after adjusting for impact factor, surgical specialty, and study type (OR $3.21,95 \%$ CI 1.81 to $5.70, \mathrm{p}<0.0001$ ). ${ }^{47}$ However, two studies reported that authors with any COI, regardless of whether disclosed or not, were significantly more likely to report positive outcomes. ${ }^{50}{ }^{52}$ In fact, in one of these studies, manuscripts in which authors fully disclosed all COI had a higher odds of providing a favourable impression of the discussed product $(12.4,95 \% \mathrm{CI}$ 4.4 to $35.4, \mathrm{p}<0.001) .^{50}$

\section{Risk-of-bias assessment}

Figure 2 depicts the risk-of-bias assessments of the 40 included studies. Several studies did not use a wideenough sample frame to address the study's target population. ${ }^{11284048495455}$ For example, some studies had a target population of all physicians but a sample frame that only included a single specialty. However, our review included a variety of specialties in order to draw inferences about physicians in general. Another possible source for bias is that included studies seldom performed a sample size calculation, as all were observational and exploratory.

\section{DISCUSSION}

\section{Statement of principal findings}

Our review identified 40 cross-sectional studies which examined the accuracy of self-reporting of financial COI by physicians. The evidence examined indicates a high prevalence of discrepancies in the reporting of financial COI among physicians across a range of academic settings and clinical specialties. Most undisclosed COI were related to expenses such as food and beverage, or travel and lodging. Undisclosed payments accounted for $33 \%$ (95\% CI $12 \%$ to $58 \%$ ) of the total payments received. The most common explanation for failure to disclose COI provided by physicians was that payments 
were 'perceived' as unrelated to the presentation or article in question. ${ }^{11}$ But in fact, a median of $45 \%$ of the non-disclosed payments from pharmaceutical companies or device manufacturers were directly or indirectly related to the published or presented academic work. We also found that smaller monetary amounts and payment irrelevance (to the article or presentation) are the most common predictors of nondisclosure among a variety of payment, author, article and journal-related factors.

\section{Strengths and weaknesses of the study}

Strengths of our review include the robust search strategy, which involved a systematic search of three databases using a broad search strategy. We identified a large number of studies enabling us to characterise discrepancies in self-reported payments across multiple settings and disciplines. We were also able to stratify discrepancies across articles, authors, authorships and payments in order to provide estimates of discrepant reporting at each of these levels.

There were several major limitations to our study. First, our exploratory meta-analysis combined data across studies to estimate the rate of discrepant reporting with more precision than is possible from a single study alone. However, the differences between the physician population and methodologies used for assessment of COI across studies resulted in high heterogeneity for pooled results. Most notably, the definition of COI employed by each of the studies varied in terms of the types and values of payments included. For example, not all studies considered food and beverage as a COI, and the threshold above which a payment was considered a COI was not consistent. In addition, a large proportion of studies did not assess relevant disclosures. While this may explain the high rate of mismatch with industry reports, our study suggests that physicians are poor assessors of relevance. Thus, the results of the exploratory analyses should be interpreted with caution and largely serve to visually illustrate the range and variability between studies. There are also limitations to the 'objective data sources' relied on for disclosures by industry. Inconsistencies in these databases, which could represent under or over-reporting by industry, have been reported.$^{28}$ While physicians are able to review this data, a challenging payment dispute process may inhibit them from attempting to correct inaccuracies. ${ }^{58}$ Moreover, with the exception of two studies from Denmark, our study is limited to physicians in the USA. Hence it does not include payments from foreign sponsors or payments to foreign physicians and may not be generalisable to other countries which do not mandate reporting of payments by industry. Nonetheless, given that many countries have made industry disclosures mandatory and regulated, we believe this is the most comprehensive source of all payment data for our analysis. Finally, there may be an element of publication bias. Studies that demonstrate a high discrepancy may be more likely to be published than studies with low discrepancies. Unfortunately, the high heterogeneity found in our exploratory meta-analyses precluded a meaningful quantitative analysis of publication bias.

\section{Strengths and weaknesses in relation to other studies}

Our results verify and extend those reported by Wayant and Vassar $^{59}$ who identified 10 studies that examined, exclusively among authors of clinical practice guidelines, the truthfulness of the reporting by physicians of financial relationships with industry. Those authors identified a pooled accuracy of $18 \%$ between actual and reported financial COIs. Our review extends these findings by evaluating physician disclosure practices among authors of both Clinical Practice Guidelines and other publications, presenters of abstracts and papers at scientific meetings and individuals organising academic meetings. We further characterised discrepancies by examining putative factors that might be associated with nondisclosure.

\section{Meaning of the study: possible explanations and implications}

Putative explanations for the high rates of nondisclosure of financial COIs by physicians rely on claims that guidelines specifying what is relevant to report are subjective and open to interpretation, although most guidelines are standardised to reduce variation and leave little room for authors to decide what relationships may be relevant to report. In 2009, a detailed disclosure form was introduced by the ICMJE, requiring all authors to disclose all relevant COI within the past 36 months, encouraging physicians to err on the side of over disclosure. ${ }^{8}$ Our review found that the accuracy of disclosure was not associated with that journal's disclosure requirements or its endorsement of ICMJE policy requirements, ${ }^{48}$ which may be related to variability of enforcement. Despite efforts to standardise the disclosure process, physicians may continue to omit reporting relevant disclosures due to false convictions that their relationships with industry do not apply to their work. ${ }^{11}$ Our meta-analysis found, however, that a significant proportion of discrepancies were related to the academic work in question, suggesting that physicians may not be the most accurate assessors of payment relevance.

The ICMJE form requires authors to specify all relationships with industry, regardless of the amount of compensation. While the amounts of unreported payments varied across studies, we found that smaller amounts were more likely to be unreported compared with larger payment amounts. In addition, general payments such as food and beverage, travel and lodging were most likely to go unreported. This is arguably due to a common perception that expenses for food or travel costs are unlikely to affect decision making and may not have equivalent importance as payments for consulting or honoraria. However, the often-advanced idea that small payments from industry are unlikely to affect physician judgement in research or medical practice is not supported by the literature. By contrast, it is clear that feelings of obligation and impulses toward reciprocity are not related to the size of a gift ${ }^{606}$; small as well as larger gifts are associated with increased rates of prescribing brand-name medications. ${ }^{62}$

The findings of this systematic review and meta-analysis suggest that changes to $\mathrm{COI}$ disclosure policies beyond those required by the ICMJE are necessary in the interests of transparency, otherwise self-reported disclosure will continue to remain an empty panacea. We agree with calls to improve disclosure through enforced, structured reporting and 
processes to assess relevance. ${ }^{63}$ One possible solution is for journals and guideline development organisations to provide authors with prepopulated disclosure forms with data extrapolated from public databases. By doing so, the bias associated with determining relevance on disclosure forms can be reduced. Authors should be provided an opportunity to confirm each COI, and provide justification for payments they consider inaccurate or irrelevant which can then be verified by an unbiased party. Ultimately, full transparency depends on moving away from entirely self-reported disclosures of payments from industry by physicians, and will require enhanced education on adequate disclosures of COI by academic institutions and stronger, well-enforced policies to address non-compliance-the violation of which result in tangible consequences. Physicians who are found to not disclose their relationships with industry should expect to face misconduct charges and academic sanctions. ${ }^{64}$ While verifying each author's disclosures may require significant time and effort by journal editors, the falsification of information that others rely on to assess that work should be an academic offence that is not tolerated.

\section{Unanswered questions and future research}

Currently, ICMJE policies require authors to only report COI within the past 36 months. However, further research is warranted to ascertain the length of time during which physicians are susceptible to industry influence after receiving funds. Future research should also investigate the effectiveness of various well-enforced COI disclosure policies. This would help better inform policies implemented by journals, guideline developing organisations and academic institutions.

\section{CONCLUSIONS}

Physician self-reports of financial COI are highly discrepant with objective data sources reporting payments from industry. Stronger policies are required by journals, guideline development organisations and academic institutions to reduce reliance on physician self-reporting of financial COI and address non-compliance.

Acknowledgements We would like to thank Kaitlin Fuller fom Gerstein Science Information Centre, University of Toronto for her assistance and guidance in creation of the search strategy.

Contributors CT developed the research question, performed the literature search, assisted with developing the search strategy, extracted the data, assessed risk of bias, and was a major contributor in writing the paper. AK assisted with developing the search strategy, completed screening, assessed risk of bias, and was a contributor in writing the paper. XL completed screening, extracted the data, assessed risk of bias, and was a contributor in writing the paper. AL completed all statistical analysis and was a contributor in writing the paper. ST assisted with the narrative synthesis and was a contributor in writing the paper. NO is the senior author and provided guidance throughout the process. All authors read and approved the final protocol.

Funding The authors have not declared a specific grant for this research from any funding agency in the public, commercial or not-for-profit sectors.

Competing interests None declared.

Patient consent for publication Not required.

Provenance and peer review Not commissioned; externally peer reviewed.
Data availability statement No additional data available.

Supplemental material This content has been supplied by the author(s). It has not been vetted by BMJ Publishing Group Limited (BMJ) and may not have been peer-reviewed. Any opinions or recommendations discussed are solely those of the author(s) and are not endorsed by BMJ. BMJ disclaims all liability and responsibility arising from any reliance placed on the content. Where the content includes any translated material, BMJ does not warrant the accuracy and reliability of the translations (including but not limited to local regulations, clinical guidelines, terminology, drug names and drug dosages), and is not responsible for any error and/or omissions arising from translation and adaptation or otherwise.

Open access This is an open access article distributed in accordance with the Creative Commons Attribution Non Commercial (CC BY-NC 4.0) license, which permits others to distribute, remix, adapt, build upon this work non-commercially, and license their derivative works on different terms, provided the original work is properly cited, appropriate credit is given, any changes made indicated, and the use is non-commercial. See: http://creativecommons.org/licenses/by-nc/4.0/.

\section{ORCID iDs}

Cameron Taheri http://orcid.org/0000-0002-5866-5617

Abirami Kirubarajan http://orcid.org/0000-0001-9807-5024

\section{REFERENCES}

1 Bekelman JE, Li Y, Gross CP. Scope and impact of financial conflicts of interest in biomedical research: a systematic review. JAMA 2003;289:454-65.

2 Neuman J, Korenstein D, Ross JS, et al. Prevalence of financial conflicts of interest among panel members producing clinical practice guidelines in Canada and United States: cross sectional study. BMJ 2011;343:d5621.

3 Schafer A. Biomedical conflicts of interest: a defence of the sequestration thesis-learning from the cases of Nancy Olivieri and David Healy. J Med Ethics 2004;30:8-24.

4 Brennan TA, Rothman DJ, Blank L, et al. Health industry practices that create conflicts of interest: a policy proposal for academic medical centers. JAMA 2006;295:429-33.

5 Field MJ, Lo B, eds. Conflict of interest in medical research, education, and practice. National Academies Press, 20090ct 16.

6 Lundh A, Lexchin J, Mintzes B, et al. Industry sponsorship and research outcome. Cochrane Database of Systematic Reviews 2017;2.

7 Brax H, Fadlallah R, Al-Khaled L, et al. Association between physicians' interaction with pharmaceutical companies and their clinical practices: a systematic review and meta-analysis. PLoS One 2017;12:e0175493.

8 Drazen JM, Van der Weyden MB, Sahni P, et al. Uniform format for disclosure of competing interests in ICMJE journals. JAMA 2010;303:75-6.

9 De Vries R, Elliott C. Why disclosure? J Gen Intern Med 2006;21:1003-4.

10 Cain DM, Loewenstein G, Moore DA. The dirt on coming clean: perverse effects of disclosing conflicts of interest. J Legal Stud 2005;34:1-25.

11 Okike K, Kocher MS, Wei EX, et al. Accuracy of conflict-of-interest disclosures reported by physicians. N Engl J Med Overseas Ed 2009;361:1466-74.

12 Norris SL, Holmer HK, Ogden LA, et al. Characteristics of physicians receiving large payments from pharmaceutical companies and the accuracy of their disclosures in publications: an observational study. BMC Med Ethics 2012;13:24.

13 Buerba RA, Fu MC, Grauer JN. Discrepancies in spine surgeon conflict of interest disclosures between a national meeting and physician payment listings on device manufacturer web sites. Spine J 2013;13:1780-8.

14 Lopez J, Samaha G, Purvis TE, et al. The accuracy of conflict-ofinterest disclosures reported by plastic surgeons and industry. Plast Reconstr Surg 2018;141:1592-9.

15 Moher D, Liberati A, Tetzlaff J, et al. Preferred reporting items for systematic reviews and meta-analyses: the PRISMA statement. Int $J$ Surg 2010;8:336-41.

16 Aromataris E, Munn Z, Aromataris E, et al. Joanna Briggs Institute Reviewer's Manual, 2017The Joanna Briggs Institute. Available: https://reviewersmanual.joannabriggs.org/

17 Taheri C, Kirubarajan A, Li X. Protocol for: discrepancies in selfreported financial Conflicts-of-Interest disclosures by physicians: a systematic review 2021. doi:10.17605/OSF.IO/FZHD7 
18 Norris SL, Holmer HK, Ogden LA, et al. Conflict of interest in clinical practice Guideline development: a systematic review. PLoS One 2011;6:e25153.

19 Campbell S. Filter to Retrieve studies related to health professionals and students from the OVID Medline database John W. Scott Health Sciences Library, University of Alberta; 2018.

20 Covidence systematic review software. Veritas health innovation, Melbourne, Australia, 2019. Available: www.covidence.org

21 Schoonjans F, Zalata A, Depuydt CE, et al. MedCalc: a new computer program for medical statistics. Comput Methods Programs Biomed 1995;48:257-62.

22 Rasmussen K, Schroll J, Gøtzsche PC, et al. Under-Reporting of conflicts of interest among Trialists: a cross-sectional study. J $R$ Soc Med 2015;108:101-7.

23 Bindslev JBB, Schroll J, Gøtzsche PC, et al. Underreporting of conflicts of interest in clinical practice guidelines: cross sectional study. BMC Med Ethics 2013;14:19.

24 Ahmed AA, Yoo SK, Mehta S, et al. Meaningful and accurate disclosure of conflict of interest at the ASTRO national meeting: a need for reassessment of current policies. $J$ Oncol Pract 2018;14:e692-8.

25 Desai MH, Vekaria DM, McKinnon BJ. Evaluating the industry relationships of presenting physicians at the American neurotological Society spring meetings. Otol Neurotol 2019;40:972-8.

26 Thompson JC, Volpe KA, Bridgewater LK, et al. Sunshine act: shedding light on inaccurate disclosures at a gynecologic annual meeting. Am J Obstet Gynecol 2016;215:661-e1.

27 Lois AW, Ehlers AP, Minneman J, et al. Disclosure at \#SAGES2018: An analysis of physician-industry relationships of invited speakers at the 2018 SAGES national meeting. Surg Endosc 2020;34:2644-50.

28 Alhamoud HA, Dudum R, Young HA, et al. Author self-disclosure compared with pharmaceutical company reporting of physician payments. Am J Med 2016;129:59-63.

29 Dudum R, Sajja A, Amdur RL, et al. Analysis of American College of Cardiology/American heart association guideline author selfdisclosure compared with open payments industry disclosure. Circ Cardiovasc Qual Outcomes 2019;12:e005613.

30 Saleh RR, Majeed H, Tibau A, et al. Undisclosed financial conflicts of interest among authors of American Society of clinical oncology clinical practice guidelines. Cancer 2019;125:4069-75.

31 Horn J, Checketts JX, Jawhar O, et al. Evaluation of industry relationships among authors of otolaryngology clinical practice guidelines. JAMA Otolaryngol Head Neck Surg 2018;144:194-201.

32 Combs T, Tritz D, Ivy H, et al. Financial conflicts of interest among authors of clinical practice guidelines for routine screening mammography. J Am Coll Radiol 2019;16:1598-603.

33 Checketts JX, Sims MT, Vassar M. Evaluating industry payments among dermatology clinical practice guidelines authors. JAMA Dermatol 2017;153:1229-35.

34 Carlisle A, Bowers A, Wayant C, et al. Financial conflicts of interest among authors of urology clinical practice guidelines. Eur Urol 2018;74:348-54.

35 Andreatos N, Zacharioudakis IM, Zervou FN, et al. Discrepancy between financial disclosures of authors of clinical practice guidelines and reports by industry. Medicine 2017;96:e5711.

36 Bansal R, Khan R, Scaffidi MA, et al. Undisclosed payments by pharmaceutical and medical device manufacturers to authors of endoscopy guidelines in the United States. Gastrointest Endosc 2020;91:266-73.

37 Boddapati V, Fu MC, Nwachukwu BU, et al. Accuracy between AJSM author-reported disclosures and the centers for Medicare and Medicaid services open payments database. Am J Sports Med 2018;46:969-76.

38 Bellomo TR, Hwang C, Spector-Bagdady K, et al. Industry compensation and self-reported financial conflicts of interest among authors of highly cited peripheral artery disease studies. J Vasc Surg 2020;72:673-84.

39 Kesselheim AS, Wang B, Studdert DM, et al. Conflict of interest reporting by authors involved in promotion of off-label drug use: an analysis of Journal disclosures. PLoS Med 2012;9:e1001280.

40 Fu MC, Boddapati V, Nwachukwu BU, et al. Conflict-of-interest disclosures to the Journal of Bone \& Joint Surgery: the relevance of industry-reported payments. J Bone Joint Surg Am 2018;100:e51.

41 Tau N, Shochat T, Gafter-Gvili A, et al. Undisclosed financial conflicts of interest of authors of clinical drug trials published in influential medical journals: a cohort study. Mayo Clin Proc 2019;94:2272-6.
42 Ross PR, Wood SM, Chung KC. Industry funding and Self-Declared conflict of interest in hand surgery publications. J Hand Surg Am 2020;45:479-87.

43 Olavarria OA, Holihan JL, Cherla D, et al. Comparison of conflicts of interest among published hernia researchers self-reported with the centers for Medicare and Medicaid services open payments database. J Am Coll Surg 2017;224:800-4.

44 Luce EA, Jackman CA. Disclosure of financial conflicts of interest in plastic and reconstructive surgery. Plast Reconstr Surg 2017;140:635-9.

45 Somerson JS, Comley MC, Mansi A, et al. Industry payments to authors of Journal of shoulder and elbow surgery shoulder arthroplasty manuscripts are accurately disclosed by most authors and are not significantly associated with better reported treatment outcomes. J Shoulder Elbow Surg 2020;29:667-73.

46 Yee C, Greenberg PB, Margo CE. Financial disclosures in academic publications and the sunshine act: a concordance study. Journal of Advances in Medicine and Medical Research 2015;19:1-6.

47 Patel SV, Yu D, Elsolh B, et al. Assessment of conflicts of interest in robotic surgical studies: validating author's Declarations with the open payments database. Ann Surg 2018;268:86.

48 Chimonas S, Frosch Z, Rothman DJ. From disclosure to transparency: the use of company payment data. Arch Intern Med 2011;171:81-6.

49 Janney CF, Shazadeh Safavi K, Schneider GJ, et al. Disclosures undisclosed. J Bone and Joint Surg 2019;101:e50.

50 Cherla DV, Viso CP, Olavarria OA, et al. The impact of financial conflict of interest on surgical research: an observational study of published manuscripts. World J Surg 2018;42:2757-62.

51 Cherla DV, Olavarria OA, Holihan JL, et al. Discordance of conflict of interest self-disclosure and the centers of Medicare and Medicaid services. J Surg Res 2017;218:18-22.

52 Cherla DV, Olavarria OA, Bernardi K, et al. Investigation of financial conflict of interest among published ventral hernia research. J Am Coll Surg 2018;226:230-4.

53 Boyll P, Neville M, Bernard R, et al. Author disclosures in plastic surgery journals compared with information reported in the open payments database: how open are we? Aesthet Surg $J$ 2019;39:338-42.

54 Chopra AC, Tilberry SS, Sternat KE, et al. Quantification of conflicts of interest in an online point-of-care clinical support website. Sci Eng Ethics 2020;26:921-30.

55 Jimbo M, Granberg CF, Osumah TS, et al. Discrepancies in self-reported and actual conflicts of interest for robotic pediatric urological surgery. J Urol 2019;201:393-9.

56 Hughes JD, Shin JJ, Albers M, et al. A closer look at the relationship between industry and orthopaedic sports medicine surgeons. Orthop J Sports Med 2019;7:232596711882317.

57 Garrett-Mayer E, Kaltenbaugh MW, Spence R, et al. Discrepancies in financial Self-Disclosures and open payments reporting among authors of clinical oncology research studies. J Clin Oncol 2020;38:480-7.

58 Sullivan T. Open payments dispute resolution call reveals tension between manufacturers and covered recipients, 2018. Available: https://www.policymed.com/2015/04/open-payments-disputeresolution-call-reveals-tension-between-manufacturers-andcovered-recipients.html

59 Wayant C, Vassar M. 3 a review of the magnitude of financial relationships with industry and disclosure practices among clinical practice guideline authors. BMJ Evidence-Based Medicine 2019;24:A2.

60 Katz D, Caplan AL, Merz JF. All gifts large and small: toward an understanding of the ethics of pharmaceutical industry gift-giving. Am J Bioeth 2010;10:11-17.

61 Dana J, Loewenstein G. A social science perspective on gifts to physicians from industry. JAMA 2003;290:252-5.

62 DeJong C, Aguilar T, Tseng C-W, et al. Pharmaceutical industrysponsored meals and physician prescribing patterns for Medicare beneficiaries. JAMA Intern Med 2016;176:1114-22.

63 Grundy Q, Dunn AG, Bero L. Improving researchers' conflict of interest declarations. BMJ 2020;368:m422.

64 Botkin JR. Should failure to disclose significant financial conflicts of interest be considered research misconduct? JAMA 2018;320:2307-8. 